\title{
Pengaruh Psychomotor Therapy pada Siswa dengan Gangguan Spektrum Autis dalam Pembelajaran Pendidikan Jasmani di Sekolah
}

\section{The Influence of Psychomotor Therapy on Students with Autistic Spectrum Disorders in Physical Education in Schools}

\author{
Lilis Maesaroh*, Bambang Abduljabar, dan Pipit Pitriani \\ Universitas Pendidikan Indonesia, Bandung, Jawa Barat, Indonesia \\ lilismh8@upi.edu*, abduljabarbambang@upi.edu,pipitpitriani18@upi.edu
}

Naskah diterima tanggal 28/07/2019, direvisi akhir tanggal 01/03/2020, disetujui tanggal 24/04/2020

\begin{abstract}
Abstrak
Penelitian ini menguji pengaruh dari aktivitas program psychomotor therapy (PMT) untuk mengurangi kondisi masalah dalam aspek perilaku, emosi, dan sosial pada anak dengan gangguan spektrum autisme usia dini. Salah satu upaya penangannya yaitu membuat anak banyak bermain dan bergerak lebih efisien melalui intervensi program $p$ sychomotor therapy. Hal tersebut menjadi alasan untuk digunakannya psychomotor therapy dimana aktivitas yang dilakukan menitikberatkan pada tubuh dan pikiran anak. Penelitian ini menggunakan metode kombinasi (mixed methods) dengan pendekatan sequential exploratory. Metode tersebut dipilih karena peneliti harus mengolah data deksripsi yang menghasilkan penjelasan mengenai kondisi objektif subjek dan pengembangan program psychomotor therapy melalui data kualitatif serta memperoleh data untuk menguji dampak suatu treatment (atau suatu intervensi) melalui data kuantitatif. Hasil dari penelitian menunjukkan bahwa terdapat penurunan frekuensi pada masalah perilaku repetitif dan perilaku emosional anak, serta terdapat penurunan latensi pada masalah sosial anak.
\end{abstract}

Kata kunci: psychomotor therapy, masalah perilaku emosional sosial, anak autis usia dini, pendidikan jasmani

\begin{abstract}
This research examines the impact of program psychomotor therapy (PMT) activities to reduce the emotional and social-behavioral problems and social aspects of children with early-age autism spectrum disorders. One of its handling efforts was to make children play and move more efficiently through the intervention of psychomotor therapy programs. It is the reason for the use of psychomotor therapy, where the activity is focused on the body and mind of the child. This research uses mixed methods with a sequential exploratory approach. The method is chosen because researchers must process the decryption data that generates explanations about the objective conditions of the subject and the development of the psychomotor therapy program through qualitative data and obtain data to test the impact of a Treatment (or an intervention) through quantitative data. The results of the study showed that there was a reduction in repetitive behavioral problems and child emotional behavior, and there was a decrease in latency to the child's social problems.
\end{abstract}

Keywords: psychomotor therapy, social emotional behavior problems, early-age autistic children, physical education 


\section{PENDAHULUAN}

Berbagai macam terapi telah banyak dilakukan untuk menangani gejala (symptom) yang terjadi pada anak autis. Penanganan pada anak autis ditujukan terutama untuk mengurangi atau menghilangkan masalah tingkah laku, meningkatkan kemampuan belajar dan perkembangannya terutama dalam keterampilan hidup sehari-hari. Terapi yang diterapkan pada anak autisme bukan hanya bersifat psikis, tetapi juga fisik, mental, emosional hingga fisiologis. Beberapa implementasinya digunakan teknik terapi, diantaranya teknik belajar dan bermain yang dapat dilakukan secara verbal maupun nonverbal (Wijayakusuma., 2004).

Abduljabar. (2012) dalam tulisannya menerangkan tentang pelaksanaan pembelajaran di sekolah yakni pendidikan jasmani adaptif yang berbasis "gerak terapi". Dikembangkan oleh para ahli di bidang Psikologi dan Motorist di berbagai negara Eropa. Konteks pembelajaran pendidikan jasmani adaptif saat ini sudah sepatutnya diperhatikan dan dipahami secara menyeluruh oleh guru pendidikan jasmani di lembaga pendidikan formal.

Terapi melalui gerak tersebut dikenal dengan istilah psychomotor therapy (PMT), memanfaatkan dua metode pokok, yaitu (1) movement-oriented-method dan (2) bodyoriented-method. Movement oriented method adalah metode yang memanfaat gerak sebagai alat terapi, gerakan dijadikan orientasi dalam setiap upaya terapi. Body oriented method adalah metode yang memanfaatkan tubuh sebagai alat terapi, unsur dalam tubuh dimanfaatkan sebagai upaya intervensi terapi (Abduljabar., 2012). Keduanya memanfaatkan gerakan dan pengalaman tubuh untuk merangsang perkembangan psikososial, mengurangi gangguan psikologis dan perilaku, meredakan gejala kejiwaan, mengurangi dampak atau gejala tertentu pada fungsi dan partisipasi anak dalam kehidupan sehari-hari (Emck et al., 2012).

Terapi psikomotorik

(PMT) dikembangkan untuk orang-orang dengan masalah kesehatan mental dan berfokus pada ekspresi dalam perilaku, gerakan, bahasa tubuh danposturberbasispengalamantubuh, bertujuan auntuk menghilangkan dan/ atau mengurangi masalah dengan menggunakan metode yang berorientasi pada tubuh dan gerakan (Houben., 2014). Tujuan dari psychomotor therapy itu sendiri menurut Probst et al., (2010) yakni PMT dapat digunakan sebagai pengobatan komplementer untuk individu dengan masalah psikologis atau perilaku, dimana rangkaian teknik berorientasi pada tubuh, seperti relaksasi progresif dan pernapasan dalam.

Saat ini, masalah autisme menimbulkan keprihatinan yang mendalam, terutama bagi kedua orang tuanya. Kebiasaan anak-anak autis sangat terganggu secara fisik maupun mental, bahkan seringkali menjadi anak-anak terisolir dari lingkungannya serta hidup dalam dunianya sendiri dengan berbagai gangguan mental dan perilaku (Jaja., 2014). Autism spectrum disorders (ASD) atau dalam bahasa gangguan spektrum autisme merupakan kelompok gangguan perkembangan (autisme, sindrom asperger, dan gangguan perkembangan pervasif yang tidak ditentukan) yang ditandai dengan gangguan komunikasi dan interaksi sosial dan terbatas, pola perilaku, minat, dan kegiatan yang berulang (Kasari \& Sterling., 2013).

Gejala-gejala autism spectrum disorders (ASD) yang paling awal diamati saat ini melibatkan perilaku dan emosi (Yuniar., 2003). Secara sederhana, perilaku dapat dikatakan sebuah gerakan yang dapat diamati dari luar. Perilaku pada anak autisme yang sering muncul adalah cara bermain yang berulang-ulang, minat yang terbatas, hambatan bersosialisasi, serta beberapa hal lain yang juga selalu melekat pada anak penyandang autisme ditambah lagi dengan adanya respon-respon yang tidak wajar terhadap informasi sensoris yang mereka terima, misalnya: suara-suara bising, cahaya, permukaan atau tekstur dari suatu bahan tertentu (Sugiarmin., 2005). Anak autis memiliki gangguan pengolahan sensorik (sensory processing disorder) sehingga muncul tingkah laku hiperaktif, bermasalah dalam melakukan gerakan, memiliki tonus otot yang lemah, dan sulit berkonsentrasi. Gangguan ini memunculkan sekumpulan simptom/ gejala yang merupakan respon aversif terhadap stimulus sensorik yang sebenarnya tidak berbahaya (Kranowitz., 2005). 
Permasalahan lain yang dialami invidu autisme adalah masalah komunikasi dan interaksi sosial. ASD biasanya didiagnosis pada anak usia dini dan ditandai oleh defisit dalam komunikasi sosial dan interaksi sosial, dibatasi pola perilaku atau aktivitas yang berulang (American Psychiatric Association., 2013). Perilaku terbatas dan berulang adalah fitur inti dari gangguan spektrum autisme. Hal itu menjadi penghalang utama bagi pembelajaran dan adaptasi sosial anak, tetapi penelitian tentang definisi, penyebab, dan kapasitas untuk perubahan cenderung diabaikan (Leekam et al., 2011).

Minat terbatas dan perilaku berulang adalah gejala klinis yang sering dilaporkan menjadi persoalan bagi orang-orang disekitar anak autisme. Anak menjadi sangat kaku dengan jadwal dan rutinitas, serta sulit berpikir luwes. Sering, orang tua langsung berusaha menghentikan perilaku repetitif anak karena dianggap mengganggu. Namun, apa yang terjadi kemudian adalah anak malah menunjukkan perilaku sulit, seperti marah dan frustasi ketika menghadapi perubahan. Tidak jarang, perilaku tersebut membuat keluarga ataupun orang lain disekitarnya kewalahan dan putus asa.

Kemudian, masalah komunikasi pada anak autis sering dimanifestasikan oleh perilaku nonverbal yang aneh, nada bicara yang aneh, sedikit hingga tidak ada ekspresi wajah atau gerakan tubuh, kesulitan memahami ucapan atau menggunakan bahasa untuk tujuan percakapan, dan kekhasan ucapan (misalnya echolalia, pembalikan pronominal), serta kegagalan mempertahankan kontak mata yang tepat (Kim., 2016). Tidak adanya kontak mata dari anak autisme membuat mereka sulit untuk memfokuskan diri dalam mengamati suatu benda sehingga kerap timbul rasa depresi jika mereka dihadapkan pada objek-objek yang masih asing (Wijayakusuma., 2004).

Dari uraian Kasari dan Sterling. (2013) banyak anak autis tidak memiliki hasrat sosial untuk berhubungan dengan orang-orang lain disekitarnya. Akibatnya, anak-anak autisme mungkin tidak menganggap diri mereka dalam hal hubungannya dengan orang lain, dan mereka mungkin lebih jarang melihat diri mereka sebagai teman bagi orang lain (Locke et al., 2010).

Seiring berkembangnya ilmu pengetahuan, saat ini PMT sendiri ditawarkan di beberapa setting, seperti pusat perawatan kesehatan mental, pusat kejiwaan anak, perawatan remaja, pendidikan khusus, perawatan untuk orang-orang dengan cacat intelektual, pengaturan rehabilitasi dan praktik pribadi (Houben., 2014). Psychomotor therapy dapat diterapkan di lembaga formal di sekolah luar biasa melalui pembelajaran pendidikan jasmani, melihat karakter PMT itu sendiri memanfaatkan dan mengadaptasi gerak tubuh manusia dalam situasi olahraga atau aktivitas fisik melalui hubungan intervensi dan respon antara guru dan siswa pada cara siswa berpikir, merasakan dan melakukan aktivitas jasmani yang dirancang guru pendidikan jasmani adaptif di sekolah (Abduljabar., 2012).

Pendidikan jasmani merupakan bagian integral dari keseluruhan proses pendidikan dan bertujuan mengembangkan: secara fisik (physically), secara mental (mentally), secara sosial (socially), dan secara emosional (emotionally fit citizens) melalui media kegiatan fisik yang telah dipilih dan direncanakan untuk mencapai hasil tertentu (Pambudi., 2010). Houben (2014) memaparkan PMT di sekolah dapat digunakan untuk mempraktikkan perilaku yang memadai dan menyelesaikan masalah dalam pengaturan keseharian mereka. Berlatih dalam pengaturan sehari-hari (situasi dimana anak mengalami masalah), memfasilitasi generalisasi pengalaman dan perilaku yang dipelajari. Pelaksanaan tersebut menjadikan strategi pembelajaran pendidikan jasmani adaptif yang berbasis terapi melalui aktivitas gerak.

Kondisi ASD dapat menyebabkan gangguan yang serius dan meluas (pervasive) pada kemampuan berpikir, berbahasa, perasaan, dan dalam menjalin hubungan atau interaksi dengan orang lain, jika tidak adanya penanganan inetrevensi atau dibiarkan (Martorell et al., 2014). Ada tiga alasan mengapa intervensi dini sangat penting, karena untuk mengoptimalkan tingkat perkembangan anak, untuk memberikan dukungan dan bantuan kepada keluarga, dan untuk memaksimalkan manfaat anak dan keluarga terhadap masyarakat sekitar (Hidayat., 2000). 
Untuk itu, perlu dilakukan intervensi dini berbasis terapi di sekolah demi mendukung perkembangan anak autis, mengurangi gejala yang ditunjukkan individu ASD juga harus diadakannya upaya memperbaiki masalah yang terjadi pada anak autis.

\section{METODE PENELITIAN}

Metode penelitian ini menggunakan metode penelitian kombinasi (mixed methods). Penggunaan mix methods research dilakukan untuk mengumpulkan data guna menjawab pertanyaan penelitian (Sugiyono., 2014). Metode kualitatif dilakukan untuk memperoleh data mengenai kondisi awal subjek dari gejala dan kondisi masalah yang terjadi sebelum diberikannya intervensi program psychomotor therapy serta langkahlangkah perancangan program psychomotor therapy yang sesuai dengan kebutuhan anak. Sedangkan, metode kuantitatif dilakukan untuk memperoleh data untuk menguji dampak suatu treatment (atau suatu intervensi) terhadap hasil penelitian.

Mixed method research mendorong peneliti untuk melakukan kolaborasi, yang tidak banyak dilakukan oleh penelitian kuantitatif maupun kualitatif. Kolaborasi dimaksud adalah kolaborasi sosial, behavioral, dan kolaborasi humanistik. Penelitian ini dilakukan dalam dua tahap dengan menggunakan desain penelitian strategi eksploratoris sekuensial. Creswell. (2014) menjelaskan pada bagan 1 bahwa strategi eksploratoris sekuensial melibatkan pengumpulan dan analisis data kualitatif pada tahap pertama, yang kemudian diikuti oleh pengumpulan dan analisis data kuantitatif pada tahap kedua yang didasarkan pada hasil-hasil tahap pertama. Desain penelitian secara visual dapat dilihat pada bagan 1 berikut.
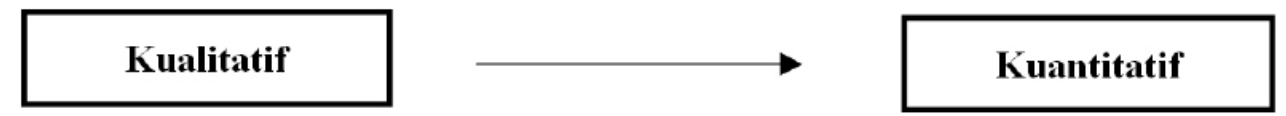

Bagan 1. Strategi Sequential Exploratory (Creswell., 2014)

Keterangan:

1. Huruf kapital pada bagan diatas menjelaskan bahwa prioritas dalam penelitian ini adalah data kualitatif.

2. Arah panah menunjukkan tahapan dalam penelitian dimulai dengan mengumpulkan data kualitatif dan analisis data kualitatif kemudian dilanjutkan dengan pengumpulan data kuantitatif dan analisis data kuantitatif. Kedua jenis data yang telah dikumpulkan dan dianalisis selanjutnya dilakukan interpretasi keseluruhan analisis.

Berikut tahapan penelitian yang dimasukkan kedalam bagan 2 .

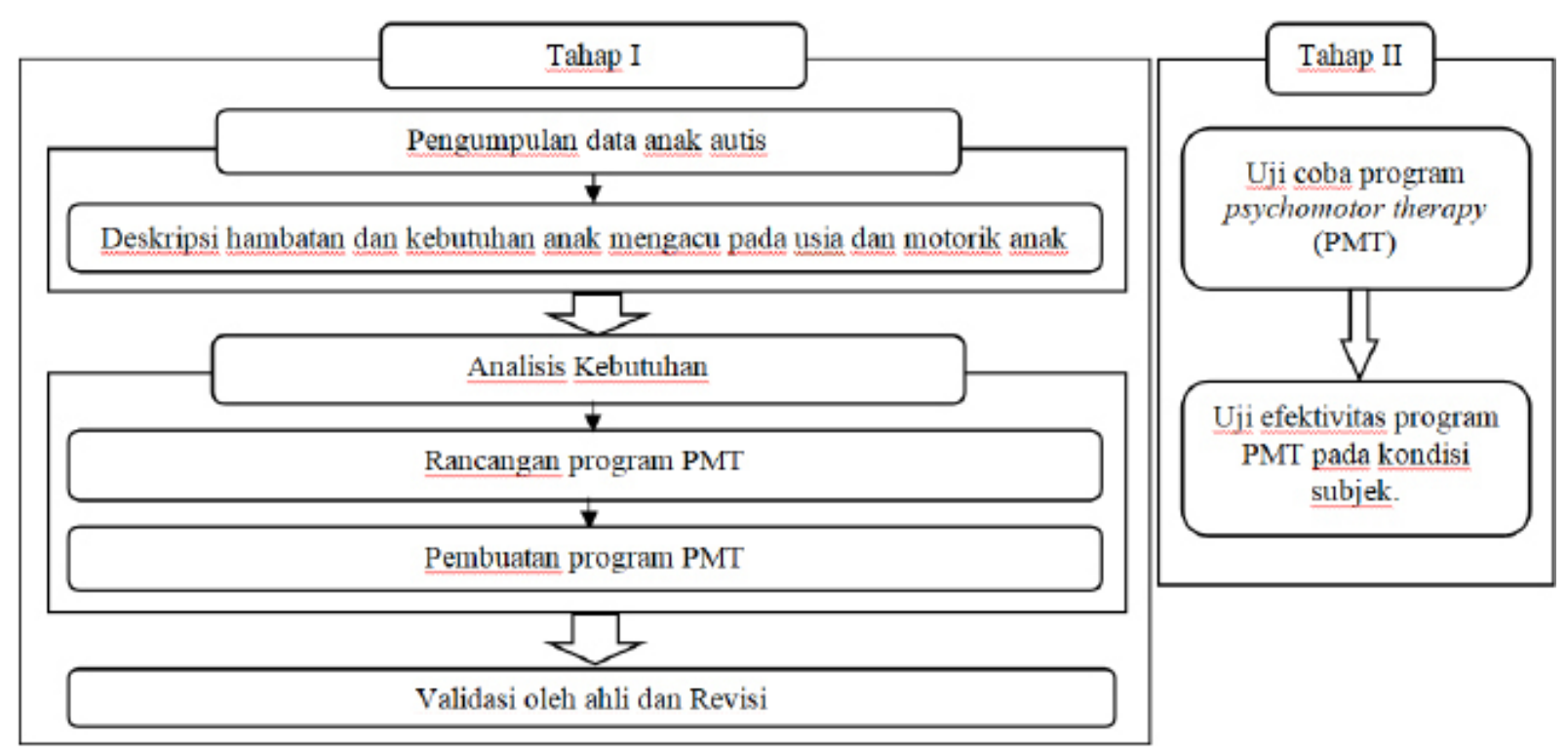

Bagan 2. Tahapan Penelitian Eksploratoris Sekuensial 


\section{HASIL DAN PEMBAHASAN}

Analisis data dalam dalam penelitian kualitatif merupakan proses pelacakan serta pengaturan secara sistematis catatan lapangan yang telah diperoleh dari wawancara, observasi, serta bahan lain agar peneliti dapat melaporkan hasil penelitian. Sedangkan dalam proses analisis data kuantitatif pada penelitian subjek tunggal banyak mempresentasikan data kedalam grafik khususnya grafik garis. Tujuan grafik garis dalam penelitian ini adalah peneliti dapat lebih mudah untuk menjelaskan terkait hasil pada sasaran perilaku (target behavior) subjek secara efisien dan detail.

\subsection{Hasil Penelitian}

\section{A. Interpretasi Hasil Observasi Kondisi Subjek}

\section{1) Aspek Visual}

Berdasarkan dari kegiatan observasi yang telah dilaksanakan, bahwa subjek tidak mengalami gangguan secara visual. Terlihat adanya kontak mata pada lawan bicaranya walaupun hanya sekilas. Subjek dapat melihat dengan baik dan fokus pada benda di sekitarnya dan mampu merespon ketika ada orang lain yang bertanya namanya. Namun jika diam, subjek cenderung berlamalama pada kondisinya yang sering melamun menatap kosong kearah yang dituju.

2) Aspek Audiotori

Berdasarkan hasil pengamatan dari segi pendengaran subjek tidak terjadi masalah. Subjek dapat mendengar bunyi atau suara dengan baik dan mampu menunjukkan respon terhadap bunyibunyian di sekitarnya. Seperti ketika adanya bunyi peluit, subjek menunjukkan respon yang mengarah pada sumber bunyi. Dapat dikatakan bahwa, dari segi audiotori, respon tersebut menunjukkan bahwa subjek dapat merespon suara dengan baik.

3) Aspek Motorik

Berdasarkan kegiatan observasi yang telah dilaksanakan, secara umum subjek memiliki kemampuan bergerak yang baik. Subjek tidak mengalami gangguan yang melibatkan fisik atau anggota tubuh. Subjek dapat menunjukkan aktivitas terkait dengan kemampuan yang melibatkan koordinasi sebagian besar anggota tubuh. Subjek sudah mampu melakukan gerakan motorik kasar, seperti naik dan turun tangga, berjalan, berlari, meloncatdengan dua kaki, melempar bola, menangkap bola. Kemudian, subjekpun sudah mampu melakukan gerakan motorik halus, seperti diantaranya menulis huruf cetak, meniru, menggunakan crayon/ pensil warna, menggambar, memotong dengan gunting.

4) Aspek Emosi

Dari hasil observasi yang dilakukan, anak memiliki gejala emosional yang nampak pada perubahan perilaku. Respon emosinya sering tidak terduga dan didominasi oleh perilaku "merengek" tanpa sebab walaupun dalam kondisi normal, seperti sedang melaksanakan pembelajaran di sekolah, ataupun dalam kondisi ia sedang berada di rumahnya. Perilaku ini diduga bahwa subjek mengalami kecemasan yang tidak stabil sehingga beberapa kali menimbulkan perilaku tersebut.

5) Aspek Sosial

Berdasarkan hasil observasi, menunjukkanbahwa subjekmemiliki minat sosial yang sangat rendah. Ia asyik untuk menyendiri pada situasi yang menurutnya mungkin nyaman bila tidak banyak orang lain disekitarnya. Pada aspek ini subjek belum mampu untuk mengembangan hubungan dengan teman sebaya dan memberikan respon sosial. Seperti belum memiliki motivasi untuk bergabung dengan teman sebaya ketika aktivitas bermain atau belajar di sekolah maupun di rumah, belum bisa memberikan walaupun sedikit respon ketika diajak bergabung dalam aktivitas permainan, cenderung menarik diri 
dari lingkungan yang ramai, seperti tidak bisa berlama-lama ketika mengikuti senam irama dengan teman-teman lainnya ataupun tidak bisa duduk nyaman ketika adanya suatu kegiatan yang melibatkan siswa-siswa lainnya.

6) Aspek Perilaku

Berdasarkan hasil observasi, adanya perilaku stereotip atau khas yaitu menutup yang terjadi pada subjek seringkali membuat para orang-orang disekitarnya bingung. Perilaku tersebut sangat tidak wajar dan cenderung mengalihkan perhatian dari orang-orang. Hal lain yang terjadi pada reaksi subjek yang terhadap stimulus lingkungan yang ramai juga kerap membuatnya berperilaku kurang menyenangkan, cemas, dan tidak nyaman.

7) Aspek Bahasa

Bahasa erat kaitannya dengan komunikasi dan interaksi. Berdasarkan hasil observasi, subjek mampu menyuarakan vokalisasi seperti menghitung angka 1-10, menyebut namanya sendiri, dan meniru kata-kata familiar yang terdengar dari orang lain.

8) Aspek Kognitif

Berdasarkan hasil observasi dalam kemampuan kognitifnya, subjek mendapat pemahaman melalui aktivitas yang bersifat simbolik serta mampu mengingat beberapa aktivitas yang telah dilaksanakan yang bersangkutan dengan dirinya.

\section{B. Analisis Kondisi Subjek}

Masalah kondisi yang dialami oleh subjek adalah menyangkut perilaku emosional dan sosial yang diperoleh melalui hasil tes selama tahap satu berlangsung. Pada tahap ini, yakni tahap dua digunakan metode single subject research (SSR). Data yang diperoleh merupakan kondisi masalah perilaku emosional dan sosial yang terjadi pada anak dalam tiap pertemuan.

Pengambilan data pada tahap baseline-1 (A-1) dilakukan sebanyak 4 (empat) sesi. Data diperoleh melalui aktivitas pembelajaran di kelas dengan didampingi guru.

Pengukuran dilakukan secara konsisten menggunakan pencatatan kejadian. Pencatatan kejadian (menghitung frekuensi) merupakan cara yang paling sederhana dan tidak memakan waktu yang banyak, yaitu dengan cara memberikan tanda (tally) pada kertas yang telah disediakan setiap kejadian atau perilaku terjadi sampai dengan periode waktu observasi yang telah ditentukan.

Berdasarkan hasil pengamatan target behavior yang diperoleh yakni tercantum pada grafik dibawah ini.

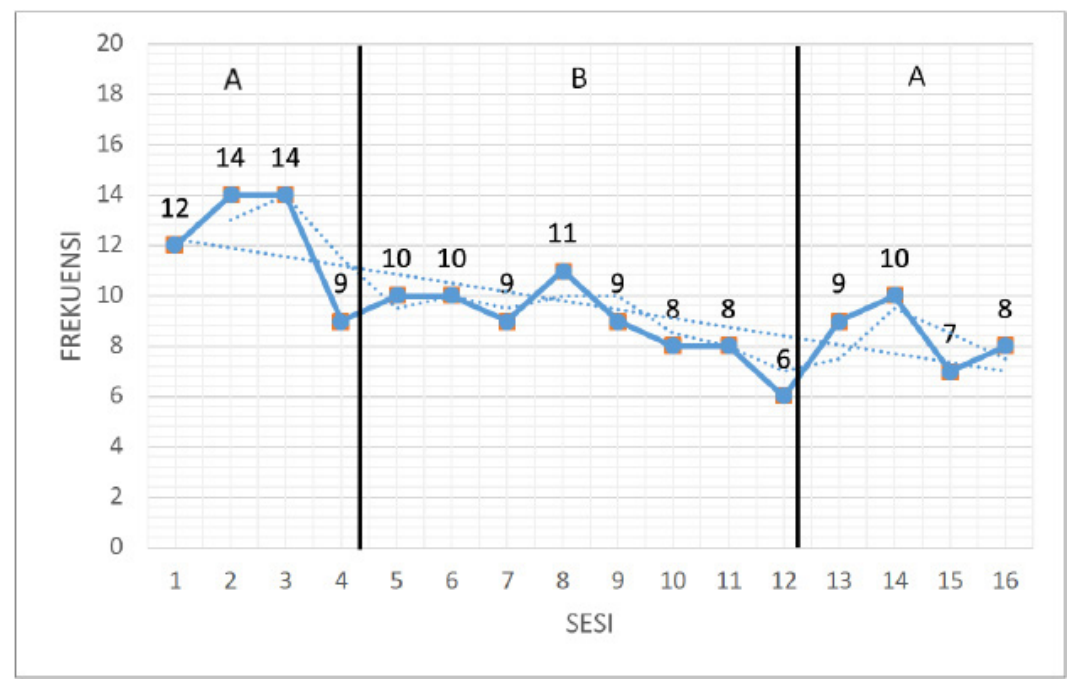

Grafik 1. Kondisi Perilaku Repetitif Anak Menutup Telinga 


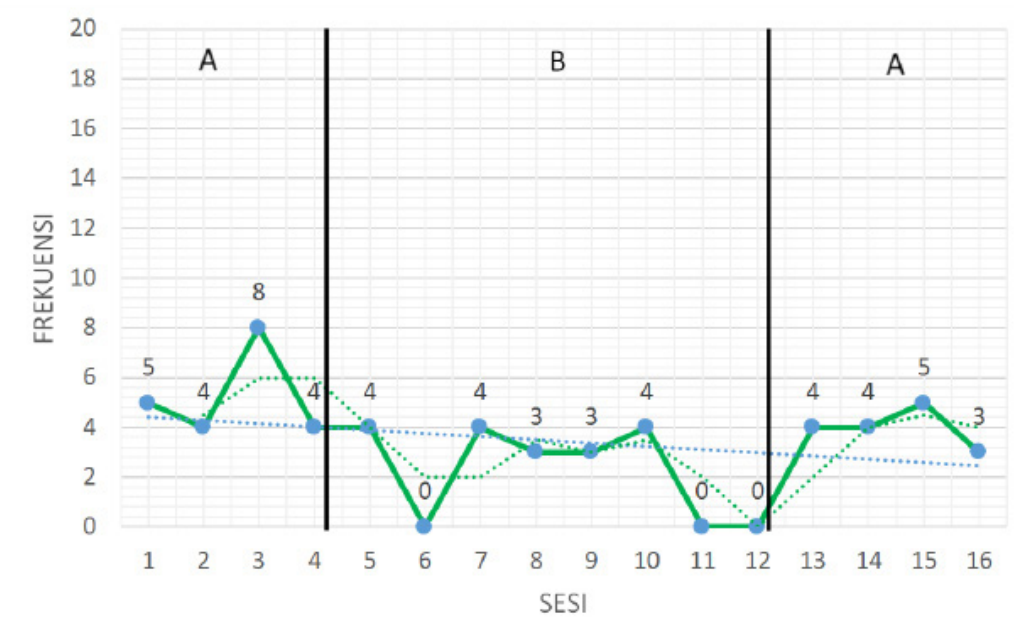

Grafik 2. Kondisi Perilaku Emosional Anak Menangis Tanpa Sebab

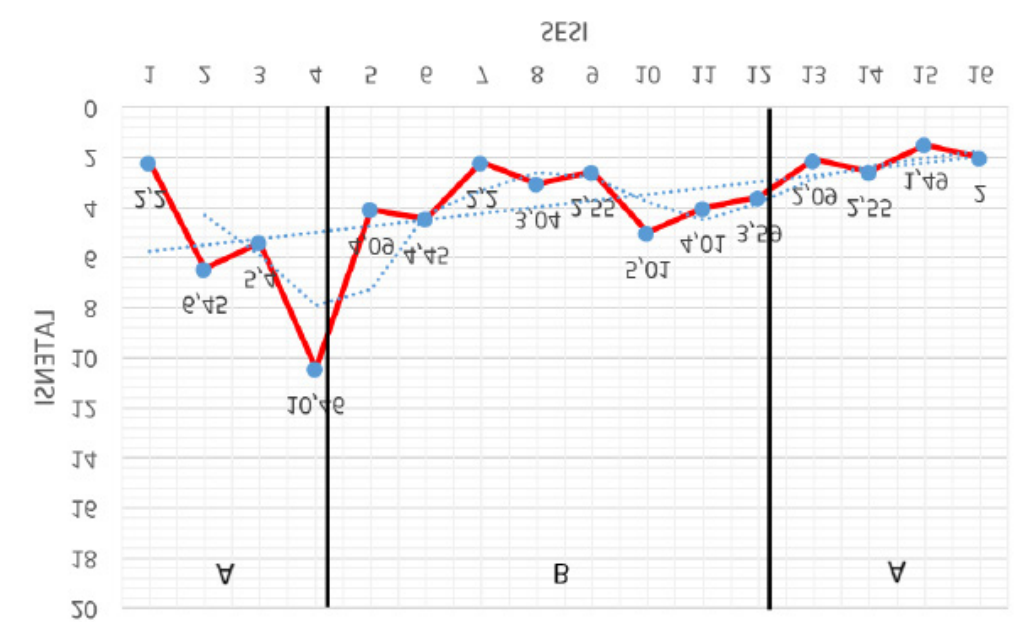

Grafik 3. Kondisi Perilaku Sosial Anak Bergabung dengan Teman

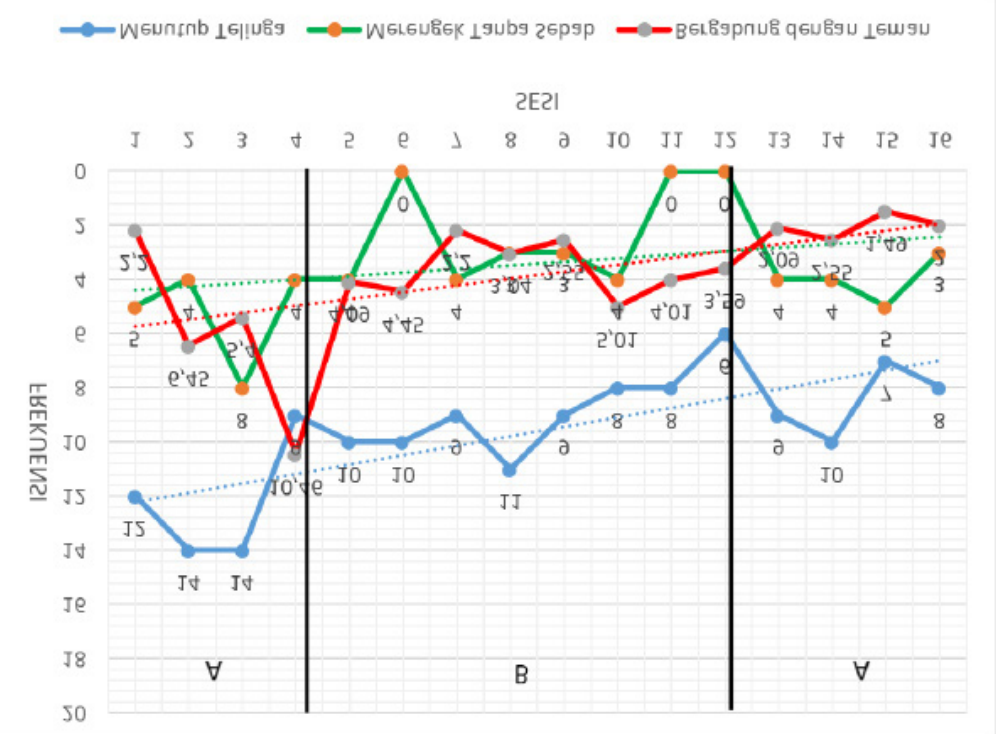

Grafik 4. Grafik Kondisi Perilaku Menutup Telinga, Merengek Tanpa Sebab, dan Bergabung dengan Teman 


\subsection{Pembahasan}

Subjek (FB) pada penelitian ini merupakan siswa autis usia dini yang saat ini berusia 9 tahun 6 bulan. Subjek merupakan anak kesatu dari dua bersaudara. Selain mendapat aktivitas pembelajaran di sekolah luar biasa, FB rutin menjalani terapi, yaitu okupasi terapi dan sensori integrasi di R.S Hermina. Jadwal terapi yang dijalaninya adalah satu minggu dua kali.

Tujuan penelitian ini yaitu untuk mengetahui pengaruh intervensi program psychomotor therapy terhadap masalah-maalah perilakuyang terjadipadaanakautis, diantaranya perilaku repetitif anak, perilaku emosional anak, dan perilaku sosial anak. Dari hasil diagnosis masalah perilaku yang terjadi yaitu anak dalam kondisi apapun sering berperilaku menutup telinga, hal tersebut merupakan salah satu gejala perilaku repetitive yang terjadi pada anak autis. Masalah perilaku emosional yang terjadi yaitu anak sering merengek tanpa sebab, mau itu di rumah maupun di sekolah. Kemudian masalah sosial yang terjadi yaitu anak tidak mampu berada pada kondisi yang ramai, memiliki pola bermain yang pasif, tidak senang berbaur dengan orang lain di sekitarnya.

Dalam proses modifikasi perilaku ada empat kegiatan utama, yaitu mengidentifikasi masalah dan mendefinisikan dalam bentuk perilaku (behavioral objective) yang teramati dan terukur; menentukan level perilaku yang akan diubah sebelum memberikan intervensi; memberikan intervensi; dan menindaklanjuti (follow up) untuk mengevaluasi apakah perubahan perilaku yang terjadi menetap atau bersifat sementara.

Dari hasil pembahasan diketahui bahwa intervensi melalui program psychomotor therapy menunjukkan arah positif terhadap kondisi masalah yang terjadi pada subjek, meliputi perilaku repetitif berupa menutup telinga pada grafik 1, perilaku emosional berupa menangis tanpa sebab grafik 2, perilaku sosial berupa anak mampu merespon untuk berada pada situasi lingkungan beserta teman-teman lainnya pada grafik 3. Dari hasil penelitian ini, masalahmasalah yang berkaitan dengan perilaku subjek yang mengalami gangguan spektrum autis menjadi berkurang setelah subjek ikutserta pada aktivitas PMT. Hasil tersebut didukung oleh hasil penelitian terdahulu Houben. (2014) yang menyatakan bahwa perlu diberlakukannya program aktivitas PMT di sekolah yang dapat ditujukan pada behavior problems and social problems yang dialami siswa. Untuk anak-anak dengan gangguan psikiatri (seperti ADHD atau PDD), psychomotor therapy (PMT) di sekolah dapat digunakan untuk praktik perilaku yang memadai dan memecahkan masalah dalam pengaturan sehari-hari mereka. Berlatih dalam pengaturan keseharian (situasi dimana anak mengalami masalah), memfasilitasi pengalaman dan perilaku anak.

Merujuk pada hasil pengamatan dan observasi di lapangan, perilaku repetitif, perilaku emosional, dan perilaku sosial yang muncul bersifat stabil-tidak stabil. Berdasarkan hasil catatan di lapangan pula, saat kondisi intervensi (B), FB selalu diberi penguatan (reinforcement), turunnya frekuensi dari fase awal hingga fase akhir. Hal ini disesuaikan dengan kaidah dalam operant conditioning sebagaimana dikemukakan oleh Sunanto. (2006) sebagai berikut :

... dalam modifikasi perilaku juga digunakan kaidah bahwa suatu perilaku apabila diberi penguatan (reinforcement) yang tepat, maka perilaku itu akan semakin dilakukan, sebaliknya jika suatu perilaku tidak diberi penguatan, maka perilaku tersebut akan terhenti.

Ini menjadi salah satu alasan pada saat kondisi intervensi melalui program PMT, masalah-masalah atas perilaku yang sering ditampilkan FB relatif berkurang atau menurun. Dilanjutkan pada kondisi A-2 dimana kondisi yang tidak melalui pemberian program PMT terjadi peningkatan pada masalah-masalah perilaku yang sebelumnya terjadi.

Sejalan dengan permasalahan yang dihadapi anak autis tersebut, selayaknya sekolah dan guru dapat menangani kondisi yang berbeda-beda pada setiap anak. Dengan bekal pengalaman melalui PMT, anak autis dapat mengontrol dirinya serta sadar betul akibat yang ditimbulkan darinya. Hal tersebut bisa diterapkan dalam kesehariannya, yaitu 
untuk melakukan hal-hal yang baik agar ia terbiasa melakukan kebiasaan baik. Anak autis memerlukan pengarahan untuk mengatur kebiasaannya. Bila ia dibiarkan saja melakukan apapun tanpa pengarahan akan berbahaya karena bisa saja menyakiti fisiknya. Kerusakan syaraf otak anak autis yang terganggu maka mereka tidak bisa optimal dalam berfikir mana yang bermanfaat dan mana yang mencelakakan. Dengan terapi serta keterlibatan pada aktivitas tubuh melalui pendidikan jasmani yang baik akan mengarahkan tingkah lakunya tersebut.

\section{KESIMPULAN}

Berdasarkan hasil analisis data penelitian, maka dapat ditarik kesimpulan bahwamasalah perilakuyangterjadipadaanak dengan gangguan autis spekrtum disorder usia dini, meliputi perilaku repetitif atau berulang barupa menutup telinga, perilaku emosional berupa anak merengek tanpa sebab, dan perilaku sosial berupa respon anak untuk senantiasa dapat bergabung dengan temantemannya. Ini menunjukkan bahwa intervensi yang diberikan yaitu aktivitas program psychomotor therapy secara signifikan dapat berpengaruh dan diterapkan pada anak autis dengan memperhatikan kemampuan serta kekurangan masing-masing anak. Frekuensi yang terjadi pada masalah-masalah perilaku tersebut menimbulkan data stabilitas yang bervariasi.

\section{DAFTAR RUJUKAN}

Abduljabar, B. (2012). Pengajaran Melalui Aktivitas jasmani Sebagai Bentuk Terapi Gerak Bagi Siswa Disabilitas di Sekolah Luar Biasa. Jurnal Pendidikan Jasmani dan Olahraga FPOK UPI Volume 2 Nomor 1 p. 82-92. ISSN: 2085-6180

American Psychiatric Association. (2013). Diagnostic and statistical manual of mental disorders (DSM-5®). Arlington, VA: American Psychiatric Publishing.

Creswell, J. W. (2014). Research Design: Qualitative, Quantitative and Mixed Methods Approaches: Fourth edition. Thousand Oaks, CA: Sage Publications.

Emck, C., Plouvier, M., \& Van Der Lee-Snel, M. (2012). Body experience in children with intellectual disabilities with and without externalising disorders. Body, Movement and Dance in Psychotherapy, 7(4), 263-275. https://doi.org/10.1080/17432979.2012.713003.

Hidayat. (2000). Identifikasi dan Asesmen Anak Autis \& Layanan Pendidikannya. Diakses dari: https:// www.google.co.id/url? sa $=t \& r c t=j \& q=\& e s r c=s \&$ source $=$ web $\& c d=1 \& c a d=r j a \& u a c t=8 \& v e d$ $=2$ ahUKEwjos 8 K0kanoAhWi8HMBHZDBC8wQFjAAegQIBxAB\&url=http\%3 A\%2F\%2Ff ile.upi.edu\%2FDirektori\%2FFIP\%2FJUR._PEND._LUAR_BIASA\%2F195707111985031HIDAYAT\%2FIDENTIFIKASI \%2526 ASESMEN ANAK AUTISx.pdf\&usg=AOvVaw1gYFUWrc M_4stsuxcNG3TI.

Houben, C. (2014). Psychomotor Therapy at School. NVPMT: Amsterdam. European Forum of Psychomotricity Journal, 2015, 6. 12- 20.

Jaja, S. (2014). Bentuk dan Metode Terapi Terhadap Anak Autisme Akibat Bentukan Perilaku Sosial. Jurnal Edueksos, III(1), 119-133.

Kasari, C., \& Sterling, L. (2013). Loneliness and Social Isolation in Children with Autism Spectrum Disorders. The Handbook of Solitude, 409-426. https://doi.org/10.1002/9781118427378.ch23.

Kim, H. S. (2016). Psychosocial Treatments for Children with Autism Spectrum Disorder. Hanyang Medical Reviews, 36(1), 27. https://doi.org/10.7599/hmr.2016.36.1.27

Kranowitz, C. S. (2005). The out-of-sync child. Recognizing and coping with sensory processing disorder. $2^{\text {nd }} e d$. New York: A Skylight Press Book.

Leekam, S. R., Prior, M. R., \& Uljarevic, M. (2011). Restricted and repetitive behaviors in autism spectrum disorders: A review of research in the last decade. Psychological Bulletin, 137(4), 562-593. https://doi. org/10.1037/a0023341.

Liu, T., \& ElGarhy, S. G. (2014). Psychomotor training program as a treatment intervention for children with autism spectrum disorder. In R. Todaro (Ed.), Physical education research: Role of school programs, children's attitudes and health implications (pp. 73- 89). Hauppauge, NY: Nova Science.

Locke, J., Ishijima, E. H., Kasari, C., \& London, N. (2010). Loneliness, Friendship Quality and the Social Networks of Adolescents with High-Functioning Autism in an Inclusive School Setting. Journal of Research in 
Special Educational Needs, 10(2), 74-81.

Loman, S. (1998). Employing a developmental model of movement patterns in dance/ movement therapy with young children and their families. American Journal of Dance Therapy, 20, 101-115.

Martorell, G., Papalia, D. E., \& Feldman, R. D. (2014). A Child's World: Infancy Through Adolescence (13th edition). USA: Mc. Graw Hill Education.

Pambudi, A. F. (2010). Target Games: Sebuah Pengembangan Konsep Diri melalui Pembelajaran Pendidikan Jasmani. Jurnal Pendidikan Jasmani Indonesia, 7(2), https://doi.org/10.21831/jpji.v7i2.418.

Probst, M., Knapen, J., Poot, G., \& Vancampfort, D. (2010). Psychomotor therapy and psychiatry: What's in a name?. The Open Complementary Medicine Journal, 2, 105-113.

Sugiarmin, M. (2012). Individu Dengan Gangguan Autisme. Dari: http://file.upi.edu/Direktori/FIP/JUR. PEND._LUAR_BIASA/195405271987031-MOHAMAD_SUGIARMIN/INDIVIDU_DENGAN_ GANGGUUAN_ĀUTISME.pdf. 25 November 2018.

Sugiyono. (2014). Metode Penelitian Kombinasi (Mixed Methods), Edisi ke- 5. Bandung: Alfabeta.

Sunanto, J. (2006). Pengantar Penelitian dengan Subject Tunggal. Bandung: UPI Press

Wijayakusuma, H. (2004). Psikoterapi Untuk Anak Autisma. Teknik Bermain Kreatif Non-Verbal. Terapi Khusus Autisma ed. 1. Jakarta: Pustaka Populer Obor.

Yuniar, S. (2003). Masalah Perilaku Pada Gangguan Spektrum Autism (GSA), (makalah). Jakarta: Konferensi Nasional Autisme-1. 